\title{
Immunoprecipitation Studies of Mycobacterial Catalase
}

\author{
LAWRENCE G. WAYNE AND GILBERT A. DIAZ \\ Tuberculosis Research Laboratory, Veterans Administration Hospital, Long Beach, California 90801, and \\ Department of Medical Microbiology, California College of Medicine, University of California, Irvine,
} California 92664

\begin{abstract}
Serological techniques have been used to detect small changes in amino acid sequences of specific proteins in closely related biological systems. These changes are believed to reflect evolutionary divergence. In the present study, the differences in binding capacities of catalases from different mycobacteria for a reference antiserum were measured very specifically by assaying the unbound functional enzyme after exposure to antibody. Catalase derived from Mycobacterium tuberculosis has been used to immunize rabbits. The antibody so produced precipitated the enzyme but did not inactivate it. This antibody also precipitated catalase from sonic lysates of other mycobacterial species. The binding capacity of catalase derived from a number of heterologous species for the M. tuberculosis antibody was always lower than that of homologous enzyme. Some species produced catalase that failed to react at all with the reference serum. In other cases, there was evidence of at least two serologically unrelated catalases in a single strain. There was also a limited correlation between rate of inactivation of catalase by heat and the relative antibody-binding capacity of the enzyme. The serological study of catalases offers promise of providing a useful tool for clarifying evolutionary relationships among mycobacterial species.
\end{abstract}

The catalase produced by Mycobacterium tuberculosis has been reported to differ from that produced by most other mycobacteria in terms of physical properties and susceptibility to inhibitors $(1,6,10)$. Catalases with different electrophoretic mobilities have been isolated from a number of mycobacterial species $(2,8,12)$. If the apparent chemical and physical differences among these enzymes were reflected in different serological specificities, this could prove to be a useful tool for taxonomic or evolutionary studies of mycobacteria and possibly for diagnostic purposes. Catalase has been isolated and purified from $M$. tuberculosis H37Rv (6), and serological properties of this product have been investigated. The relative binding of the $M$. tuberculosis catalase-specific antibody by catalase derived from a number of other mycobacterial species has also been studied.

\section{MATERIALS AND METHODS}

Cultures employed. The cultures used for this study are listed in Table 1. The matching scores (M) to the hypothetical median strains of the respective species (16) are also presented; a matching score differs from a similarity score in that it includes negative matches. The two recent clinical isolates of $M$. tuberculosis meet the usual criteria of niacin, nitrate reduction, catalase production, growth rate, presence of pigment. and isoniazid (INH) susceptibility tests for the species. The serotype numbering is based on the system of Wolinsky and Schaefer (18).

Preparation of catalase. Mycobacteria were grown and sonically treated, and the sonic extracts were clarified as described previously $(5,17)$. The clarified sonic lysate of $M$. tuberculosis was then subjected to ammonium sulfate precipitation, ionexchange chromatography, and gel filtration, as described by Diaz and Wayne (6). This purified catalase was used for most of the standardization studies to be described. Clarified sonic lysates of other species of mycobacteria were studied without further purification. All catalase-active products were diluted in, and/or dialyzed against, $0.1 \mathrm{M}$ phosphate buffer $(\mathrm{pH} 7.5)$ before use.

Hyperimmune rabbit serum. New Zealand white rabbits were inoculated intravenously with $0.3 \mathrm{ml}$ of a toluene-preserved, whole sonic lysate of $M$. tuberculosis containing $146 \mu \mathrm{g}$ of protein per $\mathrm{ml} ; 27,34$, and 41 days later they each received $0.2 \mathrm{ml}$ of a mixture of incomplete Freund adjuvant (Difco) and purified $M$. tuberculosis catalase (200 $\mu \mathrm{g}$ of protein per dose) intradermally. Fifty-four days after the last intradermal injection the rabbits received a similar dose intravenously and were bled a week later. No preservative was added to the serum because of possible interference with activity of catalase; the sera were instead divided into small portions and kept frozen at $-70 \mathrm{C}$. Control serum from other, uninoculated rabbits was stored in the same manner.

Concentration of samples. Dilute solutions of catalase and serum preparations were concentrated in disposable macrosolute concentrators (Amicon Corporation, Lexington, Mass.). Two types of concentrators were employed: a Minicon-B15, with a 5-ml load capacity and nominal molecular weight exclusion cut-off of 15,000, and a Minicon-S125, with a 1-ml load capacity and a nominal molecular weight exclu- 
sion cut-off of 125,000 . It is possible to recover 0.05 $\mathrm{ml}$ of concentrated solution with at least $90 \%$ efficiency by means of a capillary pipette.

Catalase assay. In a prior study (6), the activity of catalase preparations was based on a first-order (i.e., substrate-limiting) reaction; one unit was defined as the amount of enzyme that destroyed $90 \mu \mathrm{g}$ of $\mathrm{H}_{2} \mathrm{O}_{2}$ in $2 \mathrm{~min}$ when tested in $3 \mathrm{ml}$ of $0.01 \mathrm{M}$ phosphate buffer ( $\mathrm{pH} 7.0$ ) containing $100 \mu \mathrm{g}$ of $\mathrm{H}_{2} \mathrm{O}_{2}$ at the start of the reaction. The lower limit of reliable assay by this method was about $0.04 \mathrm{U}$ of catalase.

To increase the sensitivity of detection of catalase, an assay based on saturation kinetics was developed. The preparation to be assayed was diluted or suspended in $0.1 \mathrm{M}$ phosphate buffer (pH 7.5) containing $2 \mathrm{mg}$ of bovine serum albumin (fraction $\mathrm{V}$; Pentex) (APB). Antigen-antibody precipitates were suspended in $50 \mu \mathrm{l}$ of APB. Soluble products were diluted with $1 \mathrm{ml}$ of APB and then concentrated to 50 $\mu l$ in an appropriate macrosolute concentrator. The samples were then brought to $37 \mathrm{C}$, and $50 \mu \mathrm{l}$ of substrate $\left(2 \mathrm{mg}\right.$ of $\mathrm{H}_{2} \mathrm{O}_{2}$ per $\mathrm{ml}$ in $0.1 \mathrm{M}$ phosphate buffer, $\mathrm{pH} 7.5$ ) was added. After exactly $5 \mathrm{~min}$ of reaction time, the reaction was stopped, and the color was developed by the addition of $4.4 \mathrm{ml}$ of $\mathrm{TiCl}_{4}$ reagent $\left(0.33 \mathrm{mg}\right.$ of $\mathrm{TiCl}_{4}$ per $\mathrm{ml}$ of $\left.3 \mathrm{~N} \mathrm{H}_{2} \mathrm{SO}_{4}\right)$. Absorbance at $410 \mathrm{~nm}\left(A_{410}\right)$ was read in a $1-\mathrm{cm}$ cuvette in a Coleman Junior IIA spectrophotometer, compared with that of $\mathrm{H}_{2} \mathrm{O}_{2}$ incubated in $\mathrm{APB}$ alone, and developed with $\mathrm{TiCl}_{4}$.

Gel electrophoresis. Samples of catalase were examined for multiple bands of activity by acrylamide gel electrophoresis as described previously (6).

\section{RESULTS}

In preliminary studies of the reaction of serum from hyperimmunized rabbits, it appeared that specific antibody did not destroy the peroxide-reducing capacity of the catalase. It also did not stimulate the activity in the manner described for $\beta$-lactamase antibody (14), but the results did suggest that very small amounts of catalase-antibody complexes could be detected by use of an enzymatic assay.

Assay of catalase under conditions of saturation kinetics. When $0.1 \mathrm{U}$ of catalase was permitted to react with $100 \mu \mathrm{g}$ of $\mathrm{H}_{2} \mathrm{O}_{2}$ in a series of increasing volumes of buffer, it was seen that the rate of reaction became independent of the initial substrate concentration when that concentration exceeded $200 \mu \mathrm{g} / \mathrm{ml}$ (Fig. 1). Based on these observations, an assay was developed that employed excess substrate and saturation kinetics, permitting detection of $0.01 \mathrm{U}$ of catalase in buffer. However, because of problems encountered with adsorption on the macrosolute concentrators (see below), albumin was also incorporated into the assay system, increasing the sensitivity even further. Thus, in solutions containing at least $0.25 \mathrm{mg}$ of albumin per $\mathrm{ml}, 0.05 \mathrm{U}$ of catalase destroyed $67 \%$ of the $\mathrm{H}_{2} \mathrm{O}_{2}$
$\left(\Delta A_{410}=0.360\right)$ within $5 \mathrm{~min}$, and as little as $0.005 \mathrm{U}$ of catalase could be detected; the relationship of enzyme concentration to peroxide destruction was linear for 0.01 to $0.1 \mathrm{U}$ of enzyme (Fig. 2). Furthermore, albumin alone had no effect on the color reaction of the $\mathrm{H}_{2} \mathrm{O}_{2}$, even when as much as $50 \mathrm{mg} / \mathrm{ml}$ was present.

Recovery of catalase on macrosolute con-

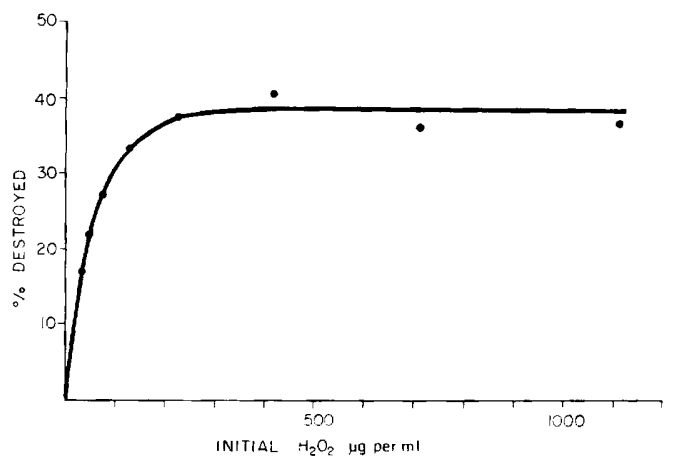

Fig. 1. Rate of destruction of hydrogen peroxide by $M$. tuberculosis catalase as a function of initial substrate concentration. Each tube contained $0.1 \mathrm{U}$ of catalase and $100 \mu \mathrm{g}$ of $\mathrm{H}_{2} \mathrm{O}_{2}$ in such volumes of $0.1 \mathrm{M}$ phosphate buffer $(\mathrm{pH} 7.5)$ as to yield the indicated initial concentrations of $\mathrm{H}_{2} \mathrm{O}_{2}$. The reaction was carried out for 2 min at $37 C$ and stopped by the addition of suitably diluted $\mathrm{TiCl}_{4}$ color reagent.

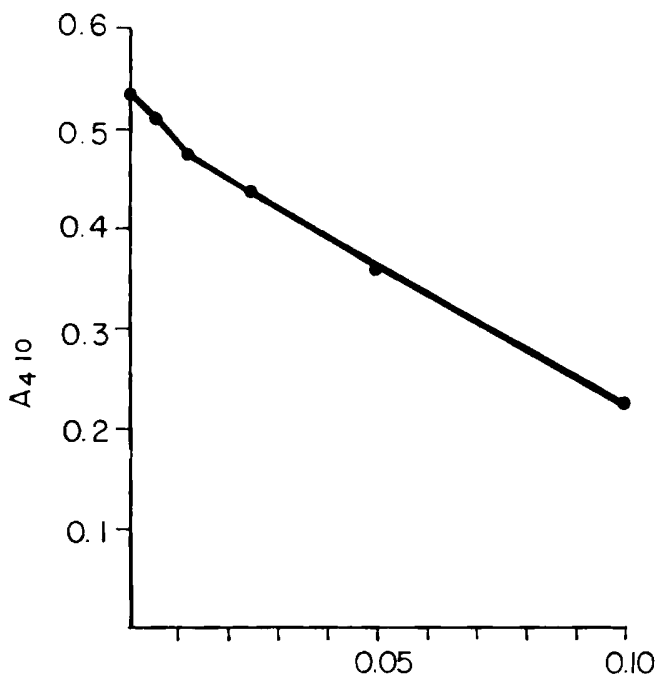

\section{UNITS OF CATALASE}

FIG. 2. Dose-response curve of catalase assayed under conditions of saturation kinetics. The graded amounts of catalase were incorporated in $50 \mu \mathrm{l}$ of $A P B$ and allowed to react for 5 min at $37 \mathrm{C}$ with 100 $\mu \mathrm{g}$ of $\mathrm{H}_{2} \mathrm{O}_{2}$ in $50 \mu \mathrm{l}$ of buffer. The residual $\mathrm{H}_{2} \mathrm{O}_{2}$ was assayed colorimetrically after development of color with $\mathrm{TiCl}_{4}$ reagent. 
centrators. To achieve efficient separation of antigen-antibody precipitates from the soluble enzyme remaining in the supernatants, it was necessary to dilute the preparations before centrifugation. However, the use of the very sensitive zero-order assay for catalase required the reaction of the enzyme and substrate in a small volume. This was achieved by reconcentrating the supernatant solutions to $50 \mu \mathrm{l}$ in a Minicon B-15 macrosolute concentrator. When solutions in buffer alone were so treated, an $85 \%$ loss of enzyme activity was observed, presumably due to adsorption onto the membrane since the exclusion limit of this membrane is of the order of 15,000 daltons. This led to exploration of the use of albumin fraction $\mathrm{V}$ to prevent this adsorption. When catalase was suspended in buffer containing $0.25 \mathrm{mg}$ or more of albumin fraction $\mathrm{V}$ per $\mathrm{ml}$, the enzyme showed a stimulation of 80 to $90 \%$ over the activity seen in buffer alone, and losses on the membrane were reduced to about 20 to $30 \%$. This loss was consistent for a given enzyme preparation and thus permitted the use of a serum-free control solution in APB, after dilution and reconcentration in a B-15 concentrator, as a base line for measuring antibody effects.

In prior studies (6) the molecular weight of $M$. tuberculosis catalase was estimated to be about 160,000 , based on its behavior on a Sephadex column. It had also been noted, however, that a dialysis membrane with a nominal exclusion limit of 50,000 daltons permitted passage of some of the catalase, suggesting a difference in conformation of protein from that of a globulin. This has been investigated further by reducing the volume of a standardized solution of the catalase in an S-125 macrosolute concentrator, which has a nominal exclusion limit of 125,000 daltons. The activity of enzyme recovered was such as to indicate free passage of catalase through the membrane rather than loss through adsorption. The S-125 concentrator thus offered a potential for use in investigating the existence of soluble antigen-antibody complexes since this membrane is capable of retaining gamma globulins.

Titration of rabbit serum against homologous antigen. After the sera raised against $M$. tuberculosis catalase were tested, one serum, identified as R.S.34, was selected for reference purposes. Serial dilutions of this serum were prepared, and $50 \mu \mathrm{l}$ of each dilution was mixed with $0.05 \mathrm{U}$ of the homologous catalase in $50 \mu \mathrm{l}$ of APB. The mixtures were incubated at $37 \mathrm{C}$ for $1 \mathrm{~h}$ and permitted to stand at $5 \mathrm{C}$ overnight. The preparations were then diluted with $1.0 \mathrm{ml}$ of APB and centrifuged at $1,300 \times g$ and $5 \mathrm{C}$ for
$60 \mathrm{~min}$. The supernatant solution was drained off and reduced to $50 \mu \mathrm{l}$ either in a B-15 macrosolute concentrator, to detect total residual soluble enzyme, or in an S-125 concentrator, to detect soluble functional enzyme-antibody complexes. The precipitates were resuspended in 50 $\mu \mathrm{l}$ of APB for an assay for activity.

The catalase disappeared from the supernatant (B) over a narrow range of serum concentrations (Fig. 3). Concurrently, the enzyme activity appeared in the precipitates (A). The average activity of duplicate precipitates diminished with further increases in serum concentration. This did not appear to be a consequence of the soluble complex in a system of antibody excess because no activity was retained in either the B-15 (B) or S-125 concentrator (C) when the system contained more than a 0.156 $\mu$ l equivalent of R.S.34. When precipitates produced by varying the amounts of serum were subjected to brief sonic treatment, the range of assay values on duplicate samples was narrowed and the difference in activity with different amounts of serum was also resolved. It thus appears that the decrease in activity of the precipitate in excess antibody is a function of the nature of the aggregate and not inactivation of enzyme, although it was never possible

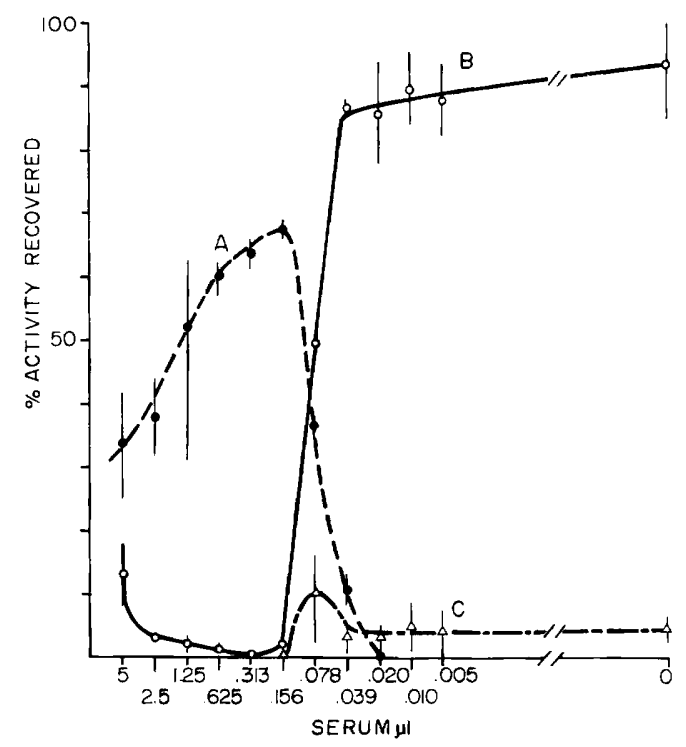

Fig. 3. Titration of $M$. tuberculosis catalase antiserum against homologous enzyme. (A) Activity in precipitate was determined after reconstitution in 50 $\mu l$ of $A P B$. (B) Total residual activity in supernate was determined after reduction to $50 \mu$ in a B-15 macrosolute concentrator. $(C)$ Attempt to detect soluble enzyme-antibody complex after reduction of supernate to $50 \mu l$ in an S-125 macrosolute concentor. 
to account for $100 \%$ of the original enzyme activity in the precipitates. The slight trace of apparent retention of activity in the S- 125 concentrator near the end point could not be reproduced in repeated narrow-range titration, and it does not appear that a soluble, enzymatically active catalase-antibody complex is formed in this system.

Survey of catalases derived from additional strains and species. The degree of serological cross-reactivity of catalase derived from a number of species of mycobacteria was studied in the following manner. Clarified sonic lysates were diluted in APB to yield $1 \mathrm{U}$ of catalase activity per $\mathrm{ml}$. Serial dilutions of serum R.S.34 and of the standardized catalase solutions were mixed and treated in the same manner as the homologous system just described. Samples $(50 \mu$ l each $)$ of the diluted catalase preparation in APB alone were also incubated at $53 \mathrm{C}$ for various times and then rapidly chilled in ice water to determine thermal inactivation rates. (The reference strain of $M$. tuberculosis catalase lost $50 \%$ of its activity after $3.4 \mathrm{~min}$ at this temperature.)

In preliminary experiments with the clarified sonic lysates and serum R.S.34, the formation of soluble, active catalase-antibody complexes was not evident by retention in the S- 125 miniconcentrator. Serological reactivity was expressed, therefore, in terms of catalase activity lost from the supernatant after centrifugation to remove the precipitate and reconcentration of supernatant on a B-15 miniconcentrator. Some representative curves from the serological titration and heat inactivation experiments are presented in Fig. 4. In the M. tuberculosis reference system (Fig. 4A), the precipitation is complete and occurs over a very narrow range; $50 \%$ precipitation occurs with a 1:640 dilution of R.S.34. In the heterologous reaction of R.S.34 with catalase from the TMC1403 strain of $M$. intracellulare (Fig. 4B), the serological end point is shifted markedly, but precipitation appears to be complete, or very nearly so. There is considerably greater divergence in serological cross-reactivity between this strain of $M$. intracellulare and the reference system than in the heat sensitivity of the catalases. When catalase from $M$. kansasii was reacted with R.S.34 (Fig. $4 C)$, only half of the activity was precipitated and only half of the activity was destroyed on prolonged heating at $53 \mathrm{C}$, indicating the presence of two dissimilar kinds of catalase. Similarly, $M$. scrofulaceum appears to have a crossreactive and a nonreactive catalase component, both of which are moderately susceptible to inactivation by heat (Fig. 4D). The curve for the

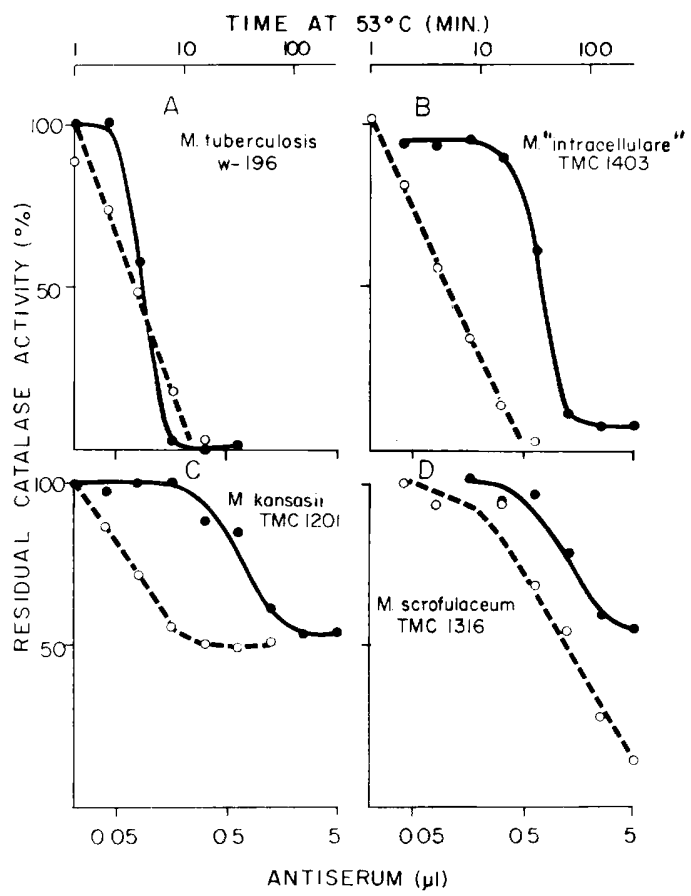

FIG. 4. Heat inactivation and serological titration curves of catalase derived from four species of mycobacteria. The solid lines represent amount of catalase remaining in the supernatant after reaction of $0.05 \mathrm{U}$ with the indicated amount of serum R.S.34. The broken lines represent residual activity after an indicated time of exposure to $53 \mathrm{C}$.

TMC1405 strain of $M$. intracellulare (Fig. 5) provides some evidence of serological heterogeneity of its catalase even though the heat inactivation curves do not.

A summary of the results of this study are presented in Table 1. The serological binding capacity is expressed in terms of units of catalase removed from the supernatant by $1 \mu \mathrm{l}$ of serum R.S.34 and was calculated from those points in the titration curve closest to the $50 \%$ end point. The immunological distance is calculated as $100 \log \mathrm{Bh} / \mathrm{Bt}$, where $\mathrm{Bh}$ is the binding capacity with the homologous reference catalase and $\mathrm{Bt}$ is the binding capacity with the heterologous test catalase. According to Prager and Wilson (13) this represents the best measure of evolutionary divergence in higher organisms.

The catalases in the different preparation are alșo characterized in terms of whether serum R.S.34 precipitates all (total), some (partial), or none of the catalase. Samples of each preparation were subjected to electrophoresis in $5 \%$ acrylamide gel, and the number of bands of 


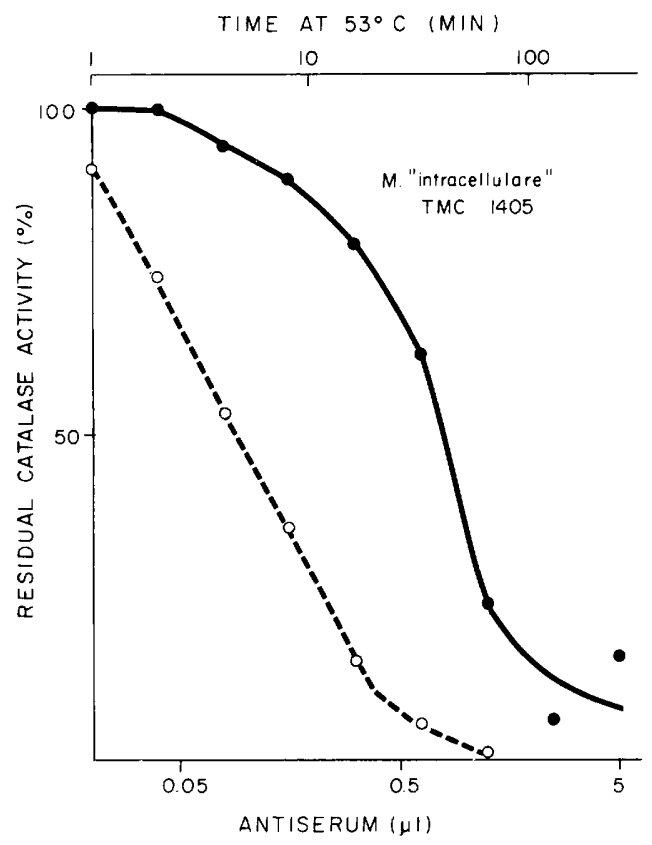

FIG. 5. Heat inactivation and serological titration curves of catalase from a strain of $M$. intracellulare that showed three bands of activity on gel electrophoresis. See legend to Fig. 4.

catalase activity was estimated after treatment with starch, $\mathrm{H}_{2} \mathrm{O}_{2}$, and $\mathrm{KI}$.

Although a very broad range of rates of inactivation of catalase at $53 \mathrm{C}$ was seen, it was possible to identify two major classes, one which exhibited 50\% inactivation in less than 4 $\mathrm{h}$, and the other requiring more than $4 \mathrm{~h}$.

The three strains of $M$. tuberculosis were homogeneous serologically as well as by criteria of thermal stability and gel electrophoresis. $M$. bovis (BCG) appeared to contain only one form of catalase, which had the greatest serological cross-reactivity to the reference system of any of the heterologous species examined. The four strains of the $M$. avium complex all showed a remarkably uniform degree of divergence from the reference system, even though at least two strains appeared to contain more than one catalase-active component. In every case in which a component that resisted inactivation at $53 \mathrm{C}$ for more than $4 \mathrm{~h}$ was present, serological cross-reactivity was either incomplete or lacking. Thus, there appear to be two major classes of mycobacterial catalase, with some further divergence of the protein structure within at least one of the classes.

\section{DISCUSSION}

Subtle changes in the amino acid sequence of specific proteins can reflect evolutionary diver- gence between closely related biological systems. These changes can be measured by serological means. Cocks and Wilson (3), using a microcomplement fixation technique, were able to detect a serological difference associated with a mutation resulting in the change of a single amino acid in the alkaline phosphatase of Escherichia coli. Prager and Wilson (13) examined lysozyme from egg white of a number of species of birds. They derived an index of dissimilarity for their system, which is based on the relative measure of antibody binding by an isozyme from a heterologous species of bird compared with that of the homologous enzyme. These investigators demonstrated that a doubling of the index of dissimilarity corresponded to a change of six amino acids in lysozyme, which has a molecular weight of about 14,000 . This correlation depends on the size of the entire molecule, and Prager and Wilson suggested that enzymes larger than lysozyme might be more suitable for evolutionary studies.

According to Cocks and Wilson (4), the immunological distance, which is a logarithmic function of the index of dissimilarity, is directly related to the percent difference in the amino acid sequence. They also suggest that a serological study of a single type of enzyme could provide the basis for taxonomic inferences.

A number of different bacterial enzymes have been studied by serological means, employing complement fixation, precipitin, and immunodiffusion assays $(4,7,9,11,15)$. The immunodiffusion reaction products cannot be measured in a highly quantitative manner and require relatively large amounts of antigen; the highly quantitative titration methods measure total reacting antigen and, thus, are best used with highly purified enzymes. The studies reported here are based on measurement of removal of specific enzyme activity and are thus suitable for use with relatively crude mixtures as long as the reference system is based on an antiserum raised against a preparation containing a single isozyme. This permits the examination of catalase derived from a variety of species without requiring a prohibitively large number of purifications.

Nevertheless, this technique does leave some questions unanswered. First, there appears to be more than one closely related catalase present in some strains. It is possible that the catalases represent functional subunits of the enzyme, and chemical fractionation of some of these products will be necessary to clarify this. Secondly, there may be additional mutant catalase proteins in these preparations which are serologically similar to the reference system 
TABLE 1. Characterization of mycobacterial catalases in terms of serological cross-reactivity, heat tolerance, and number of electrophoretic bands with catalase activity

\begin{tabular}{|c|c|c|c|c|c|c|c|c|c|c|}
\hline \multirow{2}{*}{ Species } & \multirow{2}{*}{ Strain } & \multirow{2}{*}{ Source $^{a}$} & \multirow{2}{*}{$\begin{array}{l}\text { Sero- } \\
\text { type }\end{array}$} & \multirow{2}{*}{$\begin{array}{l}\% \mathbf{M} \text { to } \\
\text { HMS }^{b}\end{array}$} & \multicolumn{3}{|c|}{ Serology } & \multirow{2}{*}{$\begin{array}{l}\text { No. of } \\
\text { gel } \\
\text { bands }\end{array}$} & \multicolumn{2}{|c|}{$\begin{array}{c}\text { Components } \\
\text { that tolerate } \\
53 \mathrm{C}\end{array}$} \\
\hline & & & & & $\begin{array}{l}\text { Binding ca- } \\
\text { pacity }^{c}\end{array}$ & $\begin{array}{l}\text { Immu- } \\
\text { nologi- } \\
\text { cal dis- } \\
\text { tance }^{d}\end{array}$ & $\begin{array}{c}\text { Extent of } \\
\text { binding }\end{array}$ & & $<4 \mathrm{~h}$ & $>4 \mathrm{~h}$ \\
\hline M. tuberculosis & W196 & A & & 100 & 0.256 & & Total & 1 & + & - \\
\hline M. tuberculosis & K5184 & B & & & 0.246 & 2 & Total & 1 & + & - \\
\hline M. tuberculosis & K5185 & B & & & 0.233 & 6 & Total & 1 & + & - \\
\hline M. bovis (BCG) & TMC 1011 & $\mathrm{C}$ & & 92 & 0.078 & 51 & Total & 1 & + & - \\
\hline M. avium & TMC 715 & $\mathrm{C}$ & 2 & 96 & 0.023 & 105 & Partial & 2 & + & + \\
\hline M. avium & TMC 716 & $\mathrm{C}$ & 1 & 83 & 0.021 & 109 & Total & 1 & + & - \\
\hline $\begin{array}{l}\text { M. avium (intra- } \\
\text { cellulare) }\end{array}$ & TMC 1403 & $\mathrm{C}$ & 14 & 90 & 0.018 & 116 & Total & $1+?$ & + & - \\
\hline $\begin{array}{l}\text { M. avium (intra- } \\
\text { cellulare) }\end{array}$ & TMC 1405 & $\mathrm{C}$ & 12 & 84 & 0.019 & 113 & Total & 3 & + & - \\
\hline M. kansasii & TMC 1201 & $\mathrm{C}$ & Kans. & 100 & 0.094 & 143 & Partial & 2 & + & + \\
\hline M. gastri & W417 & A & Gast. & 100 & 0.0051 & 170 & Total & 2 & + & - \\
\hline M. marinum & TMC 1218 & $\mathrm{C}$ & Mar. & 97 & $<0.0001$ & $>340$ & None & 4 & - & + \\
\hline M. scrofulaceum & TMC 1316 & $\mathrm{C}$ & 43 & 92 & 0.0044 & 177 & Partial & 2 & + & + \\
\hline M. scrofulaceum & TMC 1314 & $\mathrm{C}$ & 41 & 99 & $<0.0001$ & $>340$ & None & 1 & - & + \\
\hline
\end{tabular}

${ }^{a}$ Sources include: (A) this laboratory's stock collection; (B) the VA Special Reference Laboratory for Tuberculosis and Other Mycobacterial Diseases, Long Beach, Calif.; (C) Trudeau Mycobacterial Culture Collection, Saranac Lake, N.Y.

${ }^{b}$ HMS, Hypothetical median strain pattern (16); \% M, matching score (includes negative matches).

${ }^{c}$ Expressed as units of catalase activity bound by $1 \mu$ l of R.S.34.

${ }^{d}$ Expressed as $100 \log \mathrm{Bh} / \mathrm{Bt}$, where $\mathrm{Bh}$ is the binding capacity with the homologous reference catalase and $\mathrm{Bt}$ is the binding capacity with the heterologous catalase.

but for which the mutation has resulted in loss of catalase function and thus were not detected. Adsorption studies will be needed to deal with this possibility.

In spite of the unresolved problems, the method employed here shows promise of providing information that should be useful in correlating conventional taxonomic information with cladistic relationships in the genus Mycobacterium. Some degree of correlation $(\mathrm{r}=-0.71)$ is seen between the immunological distances presented here and the percent matching scores between the hypothetical median strain pattern of $M$. tuberculosis and that of six other species in a prior numerical taxonomic study of the genus (16). By development of a series of monospecific reference systems, it may be possible to triangulate the position of species in terms of immunological distances and thus construct an evolutionary map of mycobacterial species.

\section{REPRINT REQUESTS}

Address reprint requests to: Dr. Lawrence G. Wayne, Tuberculosis Research Laboratory, Veterans Administration Hospital, 5901 East Seventh St., Long Beach, Calif. 90801 .

\section{LITERATURE CITED}

1. Andrejew, A., and E. Gernez-Rieux. 1962. Essais de differenciation des Mycobacteries d'apres la sensibilite de leur activite catalasique aux inhibiteurs. Ann. Inst. Pasteur Paris 103:201-215.

2. Bartholomew, W. R. 1968. Multiple catalase enzymes in two species of mycobacteria. Am. Rev. Respir. Dis. 97:710-712.

3. Cocks, G. T., and A. C. Wilson. 1969. Immunological detection of single amino acid substitutions in alkaline phosphatase. Science 164:188-189.

4. Cocks, G. T., and A. C. Wilson. 1972. Enzyme evolution in the Enterobacteriaceae. J. Bacteriol. 110:793-802.

5. Diaz, G. A., and L. G. Wayne. 1974. Clarification of sonic lysates of Mycobacterium tuberculosis. Am. Rev. Respir. Dis. 109:154-155.

6. Diaz, G., and L. G. Wayne. 1974. Isolation and characterization of catalase produced by Mycobacterium tuberculosis. Am. Rev. Respir. Dis. 110:312-319. 
7. Gasser, F., and C. Gasser. 1971. Immunological relationships among lactic dehydrogenases in the genera Lactobacillus and Leuconostoc. J. Bacteriol. 106:113125.

8. Gruft, H., and H. A. Gaafar. 1974. Multiple catalases of mycobacteria: differences in molecular weight. Am. Rev. Respir. Dis. 110:320-323.

9. Hontebeyrie, M., and F. Gasser. 1975. Comparative immunological relationships of two distinct sets of isofunctional dehydrogenases in the genus Leuconostoc. Int. J. Syst. Bacteriol. 25:1-6.

10. Kubica, G. P., and G. L. Pool. 1960. Studies on catalase activity of acid-fast bacilli. Am. Rev. Respir. Dis. $81: 387-391$.

11. London, J., E. Y. Meyer, and S. Kulczyk. 1971. Comparative biochemical and immunological study of malic enzyme from two species of lactic acid bacteria: evolutionary implications. J. Bacteriol. 106:126-137.

12. Nakayama, Y. 1967. The electrophoretical analysis of esterase and catalase and its use in taxonomical stud- ies of mycobacteria. Jpn. J. Microbiol. 11:95-101.

13. Prager, E. M., and A. C. Wilson. 1971. The dependence of immunological cross reactivity upon sequence resemblance among lysozymes. J. Biol. Chem. 246:5978-5989.

14. Rosdahl, V. T. 1973. Naturally accurring constitutive $\beta$ lactamase of novel serotype in Staphylococcus aureus. J. Gen. Microbiol. 77:229-231.

15. Stanier, R. Y., D. Wachter, C. Gasser, and A. C. Wilson. 1970. Comparative immunological studies of two Pseudomonas enzymes. J. Bacteriol. 102:351-362.

16. Wayne, L. G. 1967. Selection of characters for an Adansonian analysis of mycobacterial taxonomy. J. Bacteriol. 93:1382-1391.

17. Wayne, L. G., and G. A. Diaz. 1974. Clarifying sonic lysates of mycobacteria. Am. Rev. Respir. Dis. 110:205.

18. Wolinsky, E., and W. B. Schaefer. 1973. Proposed numbering scheme for mycobacterial serotypes by agglutination. Int. J. Syst. Bacteriol. 23:182-183. 